place of sulphormethoxine in these conditions remains to be defined.

\section{Summary}

Sulphormethoxine is a sulphonamide with a prolonged action, which makes possible the treatment of some varieties of acute urinary tract infection with a single dose of $2 \mathrm{~g}$. In a controlled trial on ambulant patients it was as effective as a seven-day course of ampicillin given in a dose of $500 \mathrm{mg}$. eight-hourly. The cure rate was $88 \%$ with both substances. Side-effects occurred in $3.8 \%$ of patients treated with sulphormethoxine and in $16.1 \%$ of those who received ampicillin.

Sulphormethoxine is not recommended for acute pyelonephritis
Dr. Grüneberg was in receipt of a grant from the North-west Metropolitan Regional Board. Dr. I. Lennox-Smith, of Roche Products Ltd., kindly arranged for a supply of sulphormethoxine.

REFERENCES

Brit. med. F., 1964, 1, 132.

Carroll, O. M., Bryan, P. A., and Robinson, R. J. (1966). F. Amer. med. Ass., 195, 691 .

Haeg1, V (1966). Schweiz. med. W schr., 96, 1308.

Harris, M. J., Wise, G., and Beveridge, J. (1966). Aust. paediat. 7., 2, 103.

Mond, N. C., Percival, A., Williams, J. D., and Brumfitt, W. (1965). Lancet, 1, 514.

Percival, A., Brumfitt, W., and de Louvois, J. (1964). Ibid., 2, 1027.

Percival, A., Brumfitt, W., and de Louvois, J. 975.

Williams, J. D., Brumfitt, W., Leigh, D., and Percival, A. (1965). Lancot, 1, 831 .

\title{
Controlled Trial of Methandienone in Treatment of Diabetic Retinopathy
}

\author{
P. R. HUNTER,* M.A., M.B., M.R.C.P. ; SUSAN G. COTTON, $†$ M.B., M.R.C.P. ; J. H. KELSEY, $\ddagger$ M.B., F.R.C.S. \\ ARNOLD BLO.OM,§ M.D., F.R.C.P.
}

Brit. med. F., 1967, 3, 651-653

Retinopathy is a common concomitant of diabetes and is related more to the duration of the diabetic state than to any other factor. Present methods of controlling the diabetic state are unable to prevent the onset or progress of retinopathy. Several studies have claimed that diabetic retinopathy is improved by the administration of anabolic steroids (Dardenne, 1961; Houtsmuller, 1961 ; Fabrykant et al., 1964). Unfortunately the natural history of diabetic retinopathy is a variable one, and assessment of the value of therapy is correspondingly difficult. Leopold (1964) stated: "Further well controlled studies on the influence of anabolic steroids in diabetic retinopathy are mandatory."

In the present study methandienone (Dianabol) was chosen as an anabolic steroid which was effective when given by mouth, and retinal photography was used for the quantitative assessment of retinopathic changes. Forty-nine diabetic patients were observed, the double-blind method of comparing treated patients with controls being used.

\section{Design of the Trial}

Sclection of Patients.-Diabetics with retinopathy of all grades of severity (except severe retinitis proliferans) were admitted to the trial provided they had clear media. The trial started in May 1965 and ended in March 1967. Patients below 20 or over 70 years of age and those with any major illness were excluded, as were those who were unlikely to co-operate. The patients came from the diabetic clinics of a teaching and a district hospital.

Treatment and Supervision.-The patients were divided by random numbers into a group receiving oral methandienone $5 \mathrm{mg}$. twice daily and a group receiving a placebo tablet of the same size and colour, also twice a day. Patients were observed for an average of one year (span 6 to 22 months). They were seen monthly, and the following factors were among those recorded : blood pressure, blood sugar (glucose oxidase method),

\footnotetext{
* Pfizer Research Fellow, Whittington Hospital, London 19. † Medical Registrar, Whittington Hospital, London N.19. ¥ Consultant Ophthalmological Surgeon, University College Hospital, London W.C.1.

$\checkmark$ Consultant Physician, Whittington Hospital, London N.19.
}

serum cholesterol (Carr and Drekter, 1956), serum aspartate aminotransferase (Reitmann-Frankel units). Side-effects and regularity of tablet-taking were also noted.

Visual Acuity and Retinal Photography.-Visual acuity was measured before treatment, Snellen type being used. Thereafter it was assessed six-monthly. Refractive errors were corrected when present. Retinal photographs were taken on Kodachrome 2 film with a Kowa or Zeiss retinal camera. Initially multiple fields were recorded, but eventually a series of standardized fields (nasal, inferior temporal, and superior temporal) were taken of each eye. The objective was to produce three comparable fields per eye at six-monthly intervals.

\section{Assessment of Retinal Photographs}

Two assessors were present for all assessments. Standard retinal photographs as defined by Oakley et al. (1967) were used for grading the retinopathy. This system comprises the following features.

(1) The patient's photographic fields are graded by direct comparison with a set of standard fields. The grading for a whole fundus represents the average for the individual fields comprising the fundus.

(2) Five diabetic retinal abnormalities are featured:

(a) Microaneurysms and Haemorrhages.-These include all "dots" and "blots" on the retina, but exclude vitreous haemorrhages. The grading is according to the number of lesions present in the field regardless of their size.

(b) Exudates.-Hard exudates only, soft ones being ignored. As confluent exudates are common the area of retina involved, rather than the number of lesions, is used for grading.

(c) New Vessels.-All abnormal vascular channels, excepting those forming in relation to previously established fibrous retinitis proliferans. Grading according to the area of field involved.

(d) Venous Irregularities.-All venous irregularities, including dilatation, segmental irregularities, and "sausaging." Grading according to length of veins involved.

(e) Retinitis Proliferans.-Any fibrotic lesion in front of the retina, regardless of its vascular associations, and including any detectable diffuse veiling over the retinal surface. Grading according to the area of field involved. 
Soft exudates may be a specific part of diabetic retinopathy but are not included in this classification.

(3) For each retinopathic feature four standard fieids, A, B, $C$, and $D$, cnable five grades of severity to be determined.

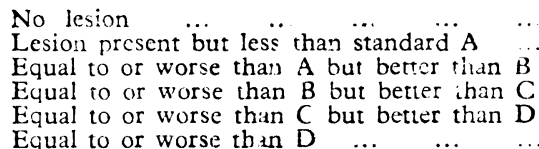

Grade 0
Grade 1
Grade 2
Grade 3
Grade 4
Grade 5

(4) Scoring System.-In order to arrive at a quantitative assessment each field was given the appropriate number for each retinopathic feature. The total of the grade numbers was divided by the number of fields to produce an average value for each feature per eye. A change for better or worse was defined as a change in one grade number in two out of three fields, or of two grade numbers in one out of three fields. In the majority of patients finally analysed two complete sets of three fields were available for each eye. Where fields showed slightly different areas non-matching parts were excluded.

\section{Results}

Sixty-two patients were admitted to the trial. Two died and 11 were withdrawn because of side-effects, unreliability, or moving out of the area. Of the 49 remaining patients, five could not be included because their photographs were not good enough. In a further 10 paiients only one eye was studied for the same reason. The total material available for study therefore constitutes 78 eyes-45 in the placebo group and 33 in the treated group. The two groups were basically similiar in respect of the initial severity of their retinopathy, the methods of treatment of their diabetes, the degree of hyperglycaemia. and the length of observation of their retinopathy.

Haemorrhages.-Patients taking methandienone showed a higher percentage of deterioration than occurred in the control group. Six patients in the treated group deteriorated as against four in the control group (Table I). In those who deteriorated the haemorrhages were more severe in the treated than in the untreated group, since in the treated group (10 eyes) the average grade number rose by 1.7 as against a rise of 1.06 in the control group ( 5 eyes). It was also noted that the haemorrhages tended to be large and multiple in the treated group. Improvement in haemorrhages occurred in only one patient in the treated group whereas it occurred in four patients in the control group. In $37.7 \%$ of controls and $48.8 \%$ of treated patients one field in six was not usable, deficiencies which cancel each other out as the error produced was in the same direction.

TABLE I.-Haemorrhages in Treated and Control Groups

\begin{tabular}{|c|c|c|c|c|c|c|}
\hline & \multicolumn{3}{|c|}{ Placebo } & \multicolumn{3}{|c|}{ Methandienone } \\
\hline & $\begin{array}{l}\text { Both } \\
\text { Eyes }\end{array}$ & $\begin{array}{c}\text { Only } \\
\text { One Eye } \\
\text { Available }\end{array}$ & $\begin{array}{c}\text { Percentage } \\
\text { of Total } \\
\text { Eyes }\end{array}$ & $\begin{array}{l}\text { Both } \\
\text { Eyes }\end{array}$ & $\begin{array}{c}\text { Only } \\
\text { One Eye } \\
\text { Available }\end{array}$ & $\begin{array}{c}\text { Percentage } \\
\text { of Total } \\
\text { Eyes }\end{array}$ \\
\hline $\begin{array}{l}\text { Improved } \\
\text { No change } \\
\text { Deteriorated }\end{array}$ & $\begin{array}{r}1 \\
12 \\
1 \\
\end{array}$ & $\begin{array}{r}3 \\
11 \\
3 \\
\end{array}$ & $\begin{array}{l}11 \cdot 1 \\
77 \cdot 8 \\
11 \cdot 1 \\
\end{array}$ & $\begin{array}{l}0 \\
8 \\
4 \\
\end{array}$ & $\begin{array}{l}1 \\
6 \\
2 \\
\end{array}$ & $\begin{array}{r}3 \cdot 0 \\
66.7 \\
30 \cdot 3 \\
\end{array}$ \\
\hline Total eyes & \multicolumn{2}{|c|}{45} & & \multicolumn{2}{|c|}{33} & \\
\hline
\end{tabular}

Exudates.-Treatment with methandienone was not associated with any overall beneficial effects on hard exudates. In a total of 15 eyes in the treated group five improved and five deteriorated, compared with the placebo group, in which in a total of 28 eyes four improved and five deteriorated. Though a higher percentage showed an improvement in the treated group, there was also a higher percentage of those who deteriorated. Two patients on methandienone showed significant improvement for exudates in one eye while deteriorating significantly in the other.
Other Lesions.-New vessels were seen in six patients, all of whom were receiving placebo tablets. In two of the six the new vessel lesion became more severe during the trial. Retinitis proliferans developed in two patients, both of whom were receiving placebo tablets. In two other patients also receiving placebos mild retinitis proliferans present at the beginning became more severe during the trial. Venous changes were not analysed because discrepancies between observers' findings made results too inconsistent to be of value.

Visual Acuity.-This was regarded as changing significantly if vision altered by two lines on a Snellen chart. Placebo and treated patients did not appear to differ significantly as regards alterations in their visual acuity. Of 25 treated patients, nine improved and two deteriorated. Of 31 untreated patients nine improved but seven deteriorated. The patient's sex did not have any consistent effect on retinal response to methandienone.

Side-effects.-Frequent questioning established that the patients took their tablets regularly. Of 30 patients on methandienone, three developed oedema, three heart failure, two a persistent rise in diastolic blood pressure, two unsteadiness on the feet and headaches, one acne and voice change, and one increased libido. In the contro! group (32 patients) one patient developed oedema and another heart failure, while two had a sustained rise of diastolic blood pressure. In both treated and placebo groups one patient died of a coronary thrombosis. It would seem that fluid retention and subjective symptoms occurred more frequently in patients on methandienone. However, it does not seem to have caused hypertension. Serum cholesterol rose on average by $108 \mathrm{mg} . / 100 \mathrm{ml}$. in the treated group, as against $43 \mathrm{mg}$. $/ 100 \mathrm{ml}$. in the untreated group. In both groups a small rise in serum transaminases occurred.

\section{Discussion}

Visual acuity is the most important of all measurements from the patient's point of view, but is an inadequate guide to retiral changes. A small haemorrhage in the region of the macula may cause a considerable loss of vision while a larger haemorrhage more peripherally may scarcely be noticed. Also, visual acuity is diminished by changes outside the retina in the lens or vitreous.

Assessment of changes in the retina can be attempted by direct ophthalmoscopy, but this clearly does not allow detailed comparison. The use of a binocular ophthalmoscope enables the fundus to be drawn while actually under observation, but this method is very time-consuming and is open to observer bias (Davis, 1965 ; Lee et al., 1966).

The retinal camera offers the best objective method of assessing changes in the retina, but it has several disadvantages. Changes in the lens or the vitreous may make photography impossible, and in some patients, particularly negroes, the pupils dilate too slowly and incompletely. It is impracticable to attempt a complete fundus map and difficult to be sure of getting comparable fields when smaller areas are examined. In this study three fields for each eye were chosen (nasal, inferior temporal, and superior temporal), and these proved adequate in practice. Nevertheless, some cases had to be discarded because the fields in series were not regarded as sufficiently comparable.

When a series of comparable retinal photographs has been obtained, the next problem to be solved is that of standards of comparison. The natural history of retinopathy is a variable one. Each component of diabetic retinal pathology may progress, regress, or remain unaltered. Haemorrhages, exudates, new vessel formation, venous dilatation, all may come and go. In this study, and in studies by other observers (Table II), about one-third of patients in the control group showed changes for better or worse while under observation. Hence there is an absolute need for standards of assessment, and in this respect 
the standard retinal photographs have proved of practical worth. Five retinopathic abnormalities have been photographed in four standard degrees of severity, and the photographs under study were graded according to these standards. In this way not only was it possible to define deterioration or improvement, it was also possible to devise a simple quantitative assessment of the extent of the changes. With the exception of venous changes, observer errors in assigning grades was slight and results were found to be reproducible.

TABLE II.-Behaviour of Exudates in Control Groups of Similar Studies (Percentage of Total Eyes)

\begin{tabular}{l|c|c|c|c} 
& $\begin{array}{c}\text { Edinburgh } \\
\text { (Cullen } \\
1.66)\end{array}$ & $\begin{array}{c}\text { Bristol } \\
\text { (Marmion and } \\
\text { Harrold, } \\
\left.1966^{*}\right)\end{array}$ & $\begin{array}{c}\text { London } \\
\text { (King } \text { et al., } \\
1963)\end{array}$ & $\begin{array}{c}\text { Present } \\
\text { Study }\end{array}$ \\
\hline $\begin{array}{l}\text { Improved } \\
\text { No change }\end{array}$ & 16 & 15 & 12 & $14 \cdot 2$ \\
$\begin{array}{l}\text { Deteriorated } \\
\text { Duration (years) }\end{array}$ & 28 & 63 & 59 & 68 \\
\hline - Personal communication. & 2 & 22 & 29 & $17 \cdot 8$ \\
\hline
\end{tabular}

Męthandienone was chosen as an agent known to be an effective anabolic steroid given by mouth, and the dosage of $5 \mathrm{mg}$. twice daily was sufficient to induce an average rise of serum cholesterol of $108 \mathrm{mg} . / 100 \mathrm{ml}$. as compared with a rise of $43 \mathrm{mg}$. $/ 100 \mathrm{ml}$. in the control group. In an ailment such as diabetes mellitus, which is known to be associated with vascular discase, this cholesterol elevation must be regarded as an unwelcome effect, especially in the long term.

The effects of methandienone on diabetic retinopathy were compared with those of placebo tablets by means of the familiar double-blind technique in which neither patient nor observer was aware of the nature of the tablets used. Assessment of the changes at the end of 18 months seemed to show an increase of haemorrhages in patients taking methandienone, and though this was not statistically significant $(P>0.12)$, it made it highly unlikely that even over longer periods any benefits would accrue.

\section{Summary}

Changes in retinopathy were assessed in two groups of diabetics, one receiving $10 \mathrm{mg}$. of methandienone daily and the other a placebo. No beneficial effect was observed in the treated group.

Assessment of changes in retinopathy was made by serial retinal photographs. These were compared with sets of standard photographs. This method of assessment proved effective and reproducible and could be used for future trials.

We acknowledge with gratitude the receipt of a grant from the North-West Metropolitan Regional Hospital Board. We are indebted to Dr. Terry Binns, CIBA Laboratories, Horsham, for his help in designing the trial and providing methandienone (Dianabol) tablets and to Mr. Peter Smith, of the M.R.C. Department of Statistics, for assistance in assessing the results. Finally we are grateful to Professor Sir Max Rosenheim for allowing us to include patients attending University College Hospital.

\section{REFERENCES}

Carr, J. J., and Drekter, I. J. (1956). Clin. Chem., 2, 353.

Dardenne, U. (1961). Acta endocr. (Kbh.), Suppl. No. 63, p. 143.

Davis, M. D. (1965). Arch. Ophthal., 74, 741.

Fabrykant, M., Gelfand, M. L., and Rosenberg, A. S. (1964). Amer. 7. med. Sci., 248, 304.

Harrold, B. P. (1966). M.D. Thesis, University of London.

Houtsmuller, A. J. (1961). Acta endocr. (Kbh.), Suppl. No. 63, p. 154.

King, R. C., Dobree, J. H., Kok, D'A., Foulds, W. S., and Dangerfield, W. G.' (1963). Brit. f. Ophthal., 47, 666.

Lee, P., McMeel, J. W., Schepens, C. L., and Field, R. A. (1966) Amer. F. Ophthal., 62, 207.

Leopold, I. H. (1964). In Diabetes Mellitus : Diagnosis and Treatment, edited by T. S. Danowski, p. 165. New York.

Oakley, N. W., Kohner, E., Hill, D. W., Joplin, G. F., and Fraser, R. (1967). Diabetologia. In press.

\section{Preliminary Communications}

\section{Fibrinolytic Activity in the Clinical Crisis of Sickle-cell Anaemia}

Brit. med. F., 1967, 3, 653-65.4

The natural history of subjects with sickle-cell anaemia is punctuated by recurrent clinical crises. There is rarely any evidence of acute haemolysis in the vast majority of episodes of crisis (Diggs, 1956), and emphasis has been placed on the finding of a variety of thromboembolic manifestations affecting almost every body organ. It is inferred that there is a marked tendency towards spontaneous vascular occlusion in sickle-cell anaemia though the mechanism remains unknown. A generally accepted conclusion is that thrombotic crises arise as a consequence of intravascular agglutination of sickled cells leading to local thrombosis and tissue ischaemia (Allison, 1956). Walters (1958) has suggested, however, that infarction might be precipitated by factors likely to influence the coagulability of the plasma, with subsequent precipitation of a fibrin reticulum within vessels. Abnormalities in coagulation factors have been reported in subjects with sickle-cell anaemia (McKellar and Dacie, 1958 ; Henstell et al., 1965), but their relation to clinical crisis has not been investigated.
The present study is an attempt to assess whether the fibrinolytic mechanism is impaired in sickle-cell anaemia, both during periods of apparent well-being and during episodes of clinical crisis.

\section{Patients AND Methods}

Children attending the sickle-cell anaemia clinic or admitted to the paediatric wards at Mulago Hospital, Kampala, were studied. All blood samples were obtained between the hours of 11 a.m. and 2 p.m., and a clean venepuncture was carried out with minimum stasis. Dilute blood clot lysis was determined with the technique of Fearnley et al. (1957) as modified by Lackner and Goosen (1959). The disintegration of the clot was taken as the end-point in this study, and clots were followed for a maximum of 24 hours. The following groups of patients were studied:

Group $A$ (37).-Hospital inpatients with haemoglobin phenotype $\mathrm{AA}$ and with a wide variety of disorders. The duration of their stay in hospital preceding examination ranged from 4 to 42 (mean 9) days.

Group $B$ (77).-Subjects with sickle-cell anaemia attending as outpatients and apparently well. 